\title{
Tribological Performance of CoCrMo Alloys with Boron Additions in As-Cast and Heat-Treated Conditions
}

\author{
Marco A. L. Hernandez-Rodriguez ${ }^{1}$, Diego E. Lozano ${ }^{2} \mathbb{D}$, Gabriela M. Martinez-Cazares ${ }^{2} \mathbb{D}$ and \\ Yaneth Bedolla-Gil ${ }^{2}$ * (D) \\ 1 Facultad de Ingeniería Mecánica y Eléctrica de la Universidad Autónoma de Nuevo León, Av. Universidad \\ S/N Ciudad Universitaria, 66451 San Nicolás de los Garza, Mexico; malhdz@gmail.com \\ 2 Departamento de Ingeniería, Universidad de Monterrey, Av. Morones Prieto 4500, 66238 San Pedro Garza \\ García, Mexico; diego.lozanod@udem.edu (D.E.L.); gabriela.martinezc@udem.edu (G.M.M.-C.) \\ * Correspondence: yaneth.bedolla@udem.edu; Tel.: +52-81-8215-1000
}

check for updates

Citation: Hernandez-Rodriguez,

M.A.L.; Lozano, D.E.;

Martinez-Cazares, G.M.; Bedolla-Gil,

Y. Tribological Performance of

CoCrMo Alloys with Boron

Additions in As-Cast and

Heat-Treated Conditions. Metals 2021,

11, 355. https://doi.org/10.3390/

met11020355

Academic Editor: Bryan Heit

Received: 6 January 2021

Accepted: 15 February 2021

Published: 19 February 2021

Publisher's Note: MDPI stays neutral with regard to jurisdictional claims in published maps and institutional affiliations.

Copyright: (c) 2021 by the authors. Licensee MDPI, Basel, Switzerland. This article is an open access article distributed under the terms and conditions of the Creative Commons Attribution (CC BY) license (https:// creativecommons.org/licenses/by/ $4.0 /$ )

\begin{abstract}
The present study evaluates the effect of boron additions on the tribological performance of CoCrMo alloys. The alloys were prepared with boron ranging from 0.06 to $1 \mathrm{wt} \%$. The materials were characterized using metallographic techniques, scanning electronic microscopy, and roughness and hardness tests. Tribological evaluation was made by means of ball-on-disc tests for sliding distances of 4,8 and $12 \mathrm{~km}$. The samples were in the as-cast condition and after a heat treatment at $1200{ }^{\circ} \mathrm{C}$ for $1 \mathrm{~h}$, finished by water quenching. The results showed that wear resistance was influenced by the microstructure and the number of secondary phases. The volume loss decreased as the boron content increased. Due to hard phases, abrasion wear was observed. Delamination fatigue was also detected after long sliding distances. Both wear mechanisms diminished in higher boron content alloys.
\end{abstract}

Keywords: CoCrMo alloys; wear resistance; boron; heat treatment; biomaterial

\section{Introduction}

CoCrMo alloys are widely used in artificial joints due to their high wear and corrosion resistance [1-3]. The clinical use of these alloys for long periods of time has shown good biocompatibility in bulk form [4]. The alloy ASTM F799, i.e., the wrought version of ASTM F75, is currently the most frequently used alloy in structural materials for permanent implants at load-bearing sites, such as artificial joints, and is intended to provide at least 20 years of service [1]. However, medical concerns exist due to metal ion release and material loss caused by tribocorrosion [5,6]. Wear debris and corrosion products have resulted in adverse local tissue reactions and implant retrieval and replacement $[1,6,7]$. The metal particles are generally very small (in the order of nanometers) and together provide a large surface area that can simplify the reaction with the medium $[6,8,9]$. Studies have been carried out to understand and improve this performance.

The typical microstructure in the casting condition of a cobalt base alloy presents a dendritic $\alpha$-FCC matrix metastable at room temperature, and precipitates composed mainly of block carbides M23C6 appearing in interdendritic regions and grain boundaries [10-12]. Coarse block carbides act as dislocation anchors and stacking faults when the material is subjected to mechanical loads although, they can also lead to fragility along the grain boundary [12-15]. A better performance in wear resistance has been found for alloys with high carbon content [5,16-18]. In addition, studies reported that a fine carbide distribution and fine grain size also enhanced the wear performance [16,19]. Although carbides are essential to strengthen CoCrMo alloys, they are also detrimental to the materials due to detachment from the matrix which leads to abrasive wear [6]. Research reported that carbides would be torn from the matrix during the tribocorrosion process due to the preferential dissolution of the boundary area under the action of galvanic corrosion and tribological contact [20]. 
The effect of boron in different cobalt-based alloys has been reported. In cobaltboron alloys microstructure refinement of columnar grains was observed due to boron additions [21]. Boron additions in the range of $0.09-1.48 \mathrm{wt} \%$ to a heat-resistant Co-based alloy found an important reduction in the incubation time of carbides, refinement of primary phases for small boron amounts, and metallic borides for larger contents [22]. Studies reported that the formation of borides around the grain boundaries improved the bond strength among the grains [23,24]; with 0.05 atom $\%$ of boron the strengthening increased creep resistance [23]. It was also observed that boron content higher than $0.04 \%$ in an atom reduced yield strength at room temperature due to precipitate-depleted zones around grain boundaries $[23,24]$. These detrimental zones were eliminated by heat treatment [24]. It was reported for a CoCrMo alloy with nickel additions and traces of aluminum, titanium, and boron that mechanical properties were improved [25]. This alloy also exhibited improved fatigue resistance due to the presence of $\mathrm{Ni}$ and the elimination of microstructural casting defects caused by trace elements [26]. Boronizing CoCrMo alloys at high temperatures formed a coating of metallic borides at the surface that improved the wear resistance due to the high surface hardness $[27,28]$. Regardless of this, a reduction in the corrosion resistance was reported [29]. A study in as-cast CoCrMo alloys with boron contents of $0.28,0.61$ and $0.98 \mathrm{wt} \%$ found important changes in the microstructure due to this element that increased the secondary phase content; wear resistance of these alloys evaluated in ball-on-disc tests increased as the boron content increased [30].

In summary, CoCrMo alloys present important advantages for their use in artificial joints; nevertheless, there are still issues due to metal ion release and material loss. The state of the art about the influence of boron on different cobalt-based alloys has been presented. In the present study, the effect of boron in the wear resistance of a CoCrMo biocompatible alloy was evaluated under as-cast and heat-treated conditions. These alloys were previously evaluated in corrosion and fatigue resistance [31,32].

\section{Materials and Methods}

\subsection{Materials}

The cobalt-based alloys studied were obtained by investment casting. The chemical composition specified in ASTM F75 was used as a reference and boron was added in $0.06,0.25,0.5$ and $1 \%$ by weight, as shown in Table 1 . The samples were studied in the as-cast condition and after a heat treatment. The heat treatment consisted of $1 \mathrm{~h}$ at $1200^{\circ} \mathrm{C}$ followed by water quenching. The identification of alloys is showed in Table 2.

Table 1. Chemical composition of the studied alloys (wt $\%$ ).

\begin{tabular}{ccccccc}
\hline $\mathbf{C r}$ & Mo & C & Si & Fe & B & Co \\
\hline $27-30$ & $8-11$ & $0.08-0.26$ & $0.17-0.74$ & $0.3-0.8$ & $0-1$ & balance \\
\hline
\end{tabular}

Table 2. Identification of materials.

\begin{tabular}{cccccc}
\hline $\mathbf{\% B}$ & $\mathbf{0}$ & $\mathbf{0 . 0 6}$ & $\mathbf{0 . 2 5}$ & $\mathbf{0 . 5}$ & $\mathbf{1}$ \\
\hline As-cast & OB-AC & 0.06B-AC & $0.25 \mathrm{~B}-\mathrm{AC}$ & $0.5 \mathrm{~B}-\mathrm{AC}$ & $1 \mathrm{~B}-\mathrm{AC}$ \\
Heat-treated & 0B-HT & 0.06B-HT & $0.25 \mathrm{~B}-\mathrm{HT}$ & $0.5 \mathrm{~B}-\mathrm{HT}$ & 1B-HT \\
\hline
\end{tabular}

The microstructure of the alloys was characterized by means of scanning electron microscopy (SEM) in a JEOL JSM-6510LV (Tokyo, Japan). Hardness was measured on an INCOR TH320 hardness tester. Microhardness was assessed with a SHIMADZU HMV. The identification of phases was performed by X-ray diffraction; results were presented in a previous study [31]. The volume fraction of the HCP phase in the alloys was quantitatively calculated according to Equation (1), using the method of Sage and Guillaud [33]. 


$$
\mathrm{HCP}(w t \%)=\frac{\mathrm{I}(10 \overline{1} 1)_{\mathrm{HCP}}}{\mathrm{I}(10 \overline{1} 1)_{\mathrm{HCP}}+1.5 \mathrm{I}(200)_{\mathrm{FCC}}}
$$

where HCP $(w t \%)$ is the fraction of martensite in weight percentage and $\mathrm{I}(200)$ and $\mathrm{I}(10 \overline{1} 1)$ are the integrated intensities of the austenite (200) and martensite (1011) peaks, respectively.

\subsection{Tribological Tests}

Tribological tests were developed in a ball-on-disc tribometer, as shown in Figure 1. The balls used were of zirconium oxide (95\% purity stabilized with $\mathrm{Y}_{2} \mathrm{O}_{3}$ ) and had a $10 \mathrm{~mm}$ diameter. The CoCrMo samples were discs of a $35 \mathrm{~mm}$ diameter with a $10 \mathrm{~mm}$ thickness. The surfaces to be evaluated were polished to a mirror finish by standard metallographic procedures. Prior to the tribological tests, the roughness ( $\mathrm{Ra}$ ) was measured using a SURFCOM 1500SD2 profilometer. During ball-on-disc tests, a load of $60 \mathrm{~N}$ was applied on the ball which corresponded to $1.81 \mathrm{GPa}$ of maximum Hertzian contact pressure. A ringer solution was used as a lubricant $\left(8.6 \mathrm{~g}\right.$ of $\mathrm{NaCl}, 0.3 \mathrm{~g}$ of $\mathrm{KCl}$ and $0.33 \mathrm{~g}$ of $\mathrm{CaCl}_{2}$ per liter of distilled water). The tests were carried out at $314 \mathrm{~mm} / \mathrm{s}$ for sliding distances of 4,8 and $12 \mathrm{~km}$. These high contact pressure and long sliding distances were chosen to achieve severe wear conditions. Three samples for every condition were evaluated. The coefficient of friction was measured every $200 \mathrm{~m}$; it is presented as an average at each point. After the ball-on-disc tests, the samples were ultrasonically cleaned in acetone for $10 \mathrm{~min}$. The volumetric wear was calculated through wear track by measuring the profiles in different zones using the profilometer. The wear tracks on the specimens were also analyzed by SEM.

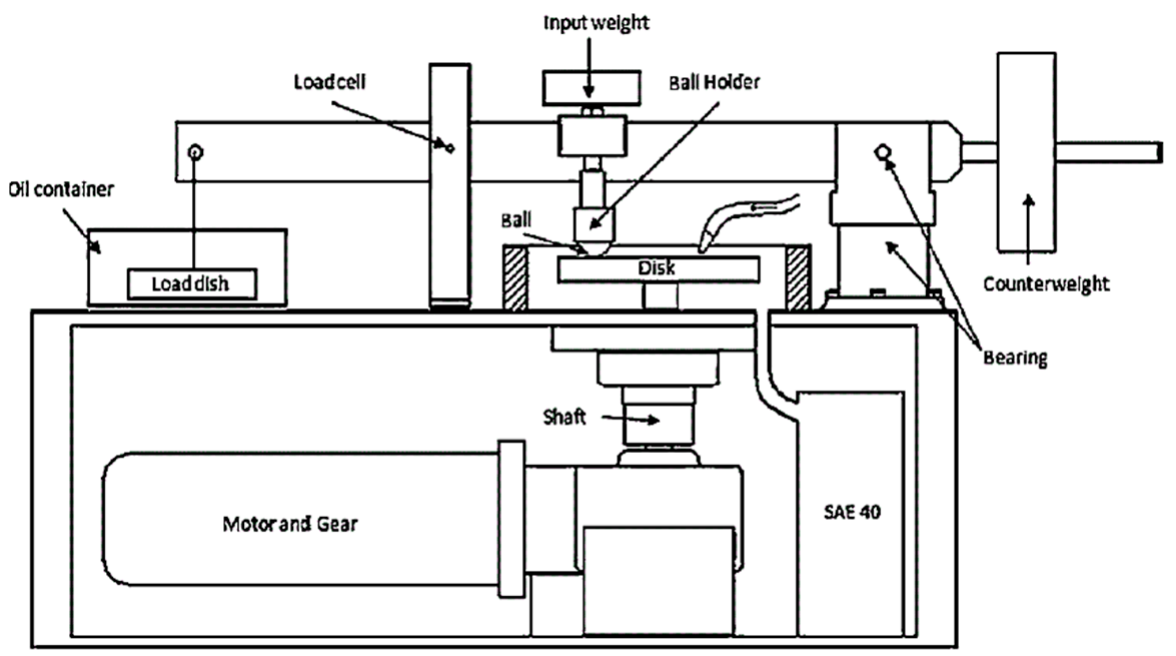

Figure 1. Ball-on-disc tribometer.

\section{Results and Discussion}

\subsection{Microstructure}

The microstructures of the alloys are presented in Figures 2 and 3 for the as-cast and heat-treated conditions, respectively. In the as-cast alloys, a change in the morphology of secondary phases can be observed, along with the increase in boron content. The heat treatment promoted a globular shape in precipitates and their even distribution in the structure. The identification of current phases in these alloys by X-ray diffraction was presented in a previous study [31]. 


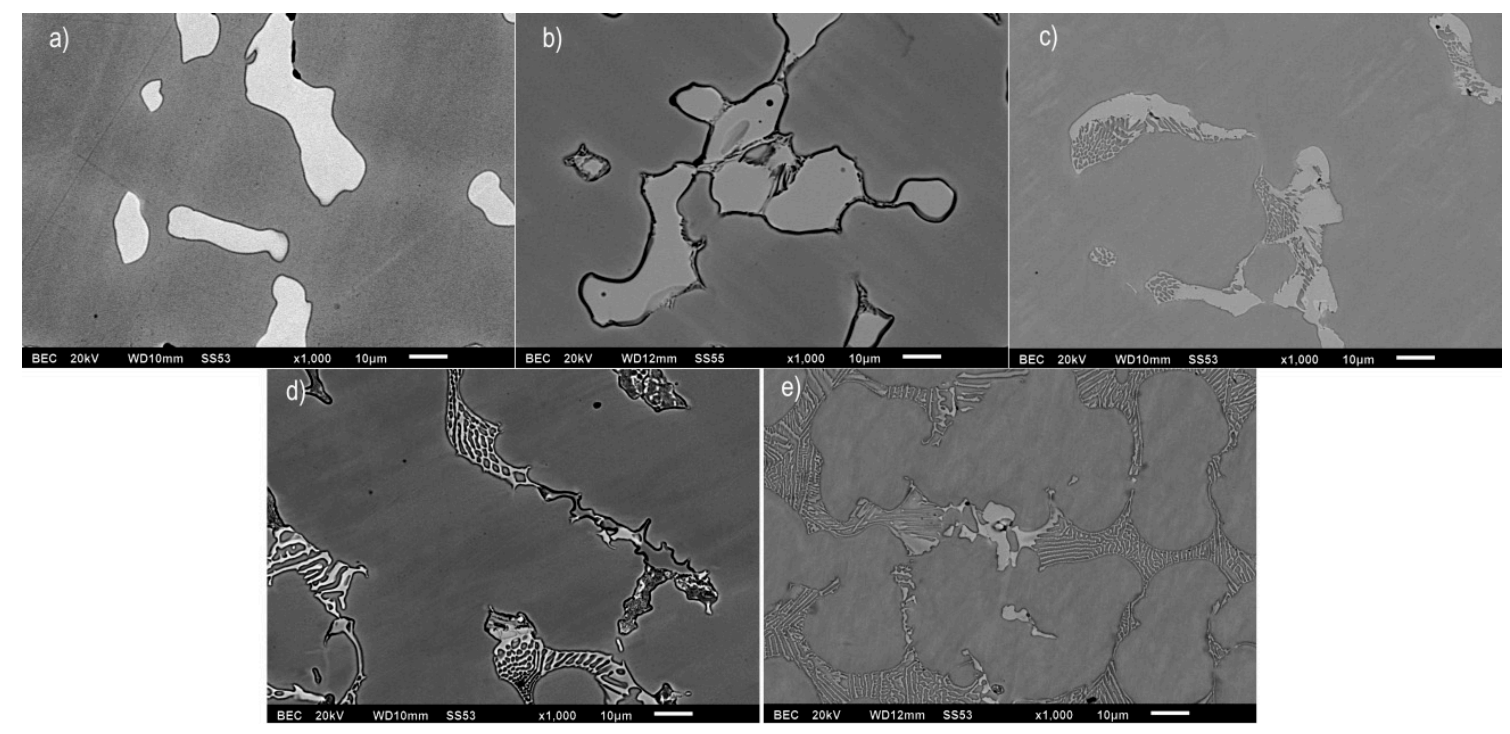

Figure 2. Microstructures in as-cast condition alloys; (a) 0B-AC, (b) 0.06B-AC, (c) 0.25B-AC, (d) 0.5B-AC and (e) 1B-AC.

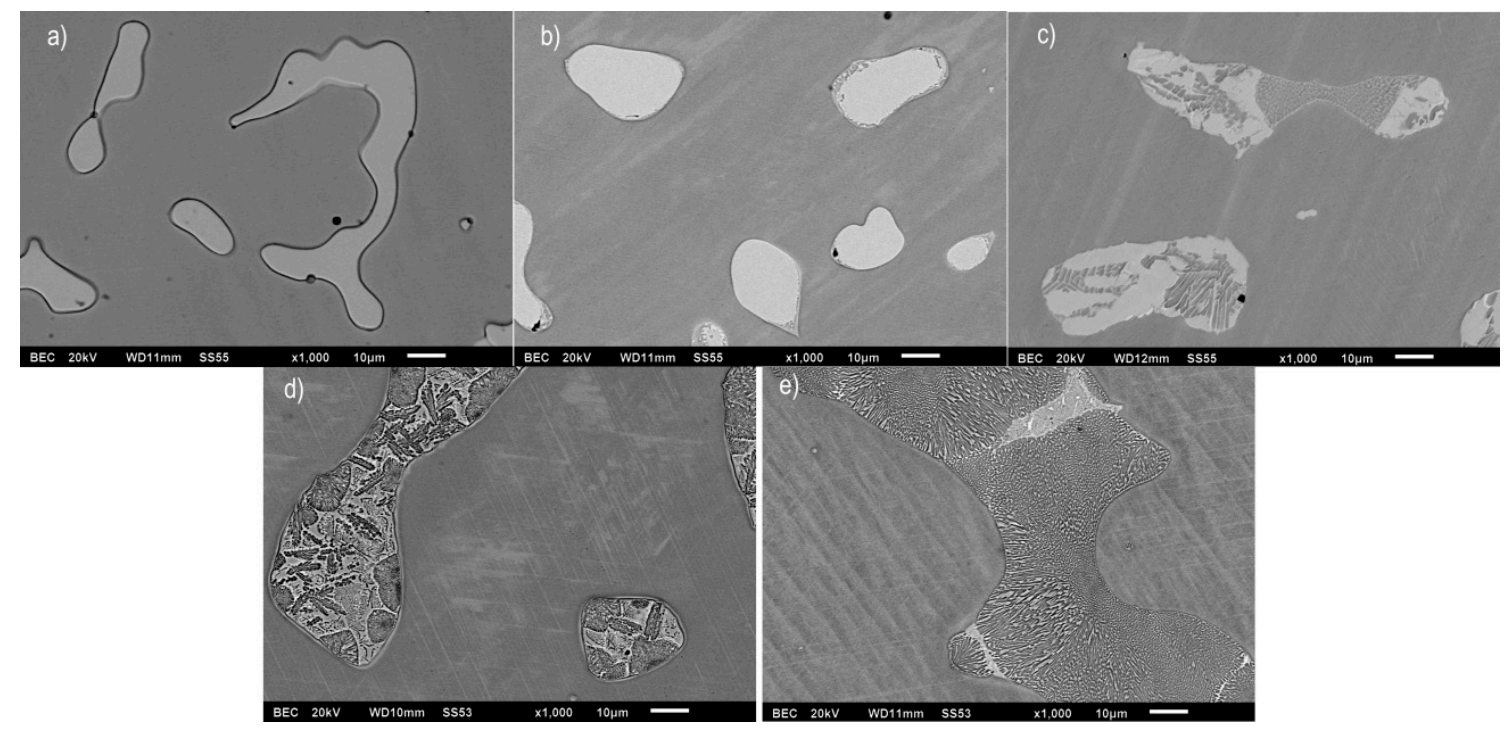

Figure 3. Microstructures after heat treatment; (a) 0B-HT, (b) 0.06B-HT, (c) 0.25B-HT, (d) 0.5B-HT and (e) 1B-HT.

Table 3 presents the amount of HCP phase in the alloys according to the Sage and Guillaud method [33]. In the reference material, the alloy without boron, a decrement in $\mathrm{HCP}$ volume fraction after heat treatment was observed, compared with the as-cast condition. This effect was also observed in the very low content alloys, the $0.06 \mathrm{~B}$. However, in the $0.25 \mathrm{~B}$ alloys, the trend changed and after heat treatment the HCP volume fraction increased; this increment was more evident in the $0.5 \mathrm{~B}$ and $1 \mathrm{~B}$ alloys. It is worth noting that in the as-cast alloys, higher boron contents diminished the HCP volume fraction; it is also more clearly observed in higher boron contents, $0.5 \mathrm{~B}-\mathrm{AC}$ and 1B-AC.

Table 3. HCP volume fractions in the alloys before wear testing.

\begin{tabular}{cccccc}
\hline B & $\mathbf{0}$ & $\mathbf{0 . 0 6}$ & $\mathbf{0 . 2 5}$ & $\mathbf{0 . 5}$ & $\mathbf{1}$ \\
\hline As-cast & 55 & 53 & 53 & 46 & 40 \\
Heat-treated & 49 & 47 & 57 & 53 & 52 \\
\hline
\end{tabular}




\subsection{Hardness and Roughness}

In Table 4, the hardness, microhardness and roughness of the alloys is presented. In the as-cast alloys, the HRC values increased along with boron content. This was attributed to the increment of hard phase precipitation due to boron. Studies reported for $\mathrm{CoCrMo}$ alloys that heat treatment at high temperatures $\left(1200-1350{ }^{\circ} \mathrm{C}\right)$ dissolved carbides into the matrix which reduced the hardness in the material $[10,19]$. In the present study, this was observed in the alloy without boron. However, in alloys with some boron content the hardness increased after heat treatment due to the enrichment of the secondary phases and the higher hardness of borides than carbides. This can be noticed in the Vickers Hardness (HV) of microstructural components (Table 4); the matrix hardness decreased after heat treatment while the secondary phases hardened. It was also observed that the precipitate hardness increased with boron content and with heat treatment.

Table 4. Hardness, microhardness and roughness of alloys.

\begin{tabular}{ccccccccc}
\hline \multirow{2}{*}{ Alloy } & \multicolumn{2}{c}{ HRC } & \multicolumn{2}{c}{ HV (Matrix) } & \multicolumn{2}{c}{ HV (Precipitates) } & \multicolumn{2}{c}{ Ra $(\mu \mathrm{m})$} \\
\cline { 2 - 9 } & AC & HT & AC & HT & AC & HT & AC & HT \\
\hline 0B & 32 & 28 & 352 & 317 & 408 & 444 & 0.026 & 0.024 \\
0.06B & 33 & 34 & 342 & 363 & 448 & 477 & 0.022 & 0.023 \\
0.25B & 34 & 36 & 401 & 338 & 525 & 516 & 0.030 & 0.026 \\
0.5B & 37 & 39 & 438 & 352 & 556 & 598 & 0.031 & 0.024 \\
1B & 39 & 45 & 511 & 416 & 610 & 643 & 0.044 & 0.030 \\
\hline
\end{tabular}

The roughness measurements show the influence of boron in surface features, as shown in Table 4 . The 0.06B-AC alloy presented a lower roughness than the as-cast alloy without boron. This could be due to the elimination of casting defects caused by the small addition of the element, as reported for trace elements [26]. Alloys with higher boron content exhibited higher roughness, up to $0.044 \mu \mathrm{m}$ in the 1B-AC alloy. The high roughness could be related to the amount of precipitates present in higher boron content alloys. The heat treatments diminished the roughness with regard to the as-cast condition, which was probably caused by the homogenization of these secondary phases.

\subsection{Tribological}

Figure 4 shows the friction coefficient obtained during the ball-on-disc tests. No direct relationship between the roughness values and friction was observed. In the as-cast condition, the 0.06B-AC alloy, that exhibited the lowest roughness, also showed one of the highest friction coefficients. The 0.25B-AC and 0.5B-AC alloys had comparable Ra, but their friction coefficient was not similar. The $0.5 \mathrm{~B}-\mathrm{AC}$ alloy showed the lowest friction coefficient while in the $0.5 \mathrm{~B}-\mathrm{HT}$ the largest one was observed; the $0.5 \mathrm{~B}$-AC had higher roughness than the $0.5 \mathrm{~B}-\mathrm{HT}$. The friction coefficient could be related to the wear mechanisms that acted at the different stages of the tribological tests; Section 3.4 presents the surface analysis.

Figure 5 presents the volumetric wear measured according to material condition, boron content and the sliding distance. In as-cast condition, a high volumetric wear can be observed in the $\mathrm{OB}-\mathrm{AC}$ alloy, especially after $12 \mathrm{~km}$. For this alloy without boron, the heat treatment improved its wear resistance, particularly in the long sliding distance where a reduction of $60 \%$ was observed; for 4 and $8 \mathrm{~km}$ the volumetric wear was similar to the as-cast condition. The volume loss considerably decreased with the increment in boron content in the as-cast condition alloys, as previously reported [30]. For heat-treated alloys, the volume wear loss was in general comparable to that in the as-cast condition. 


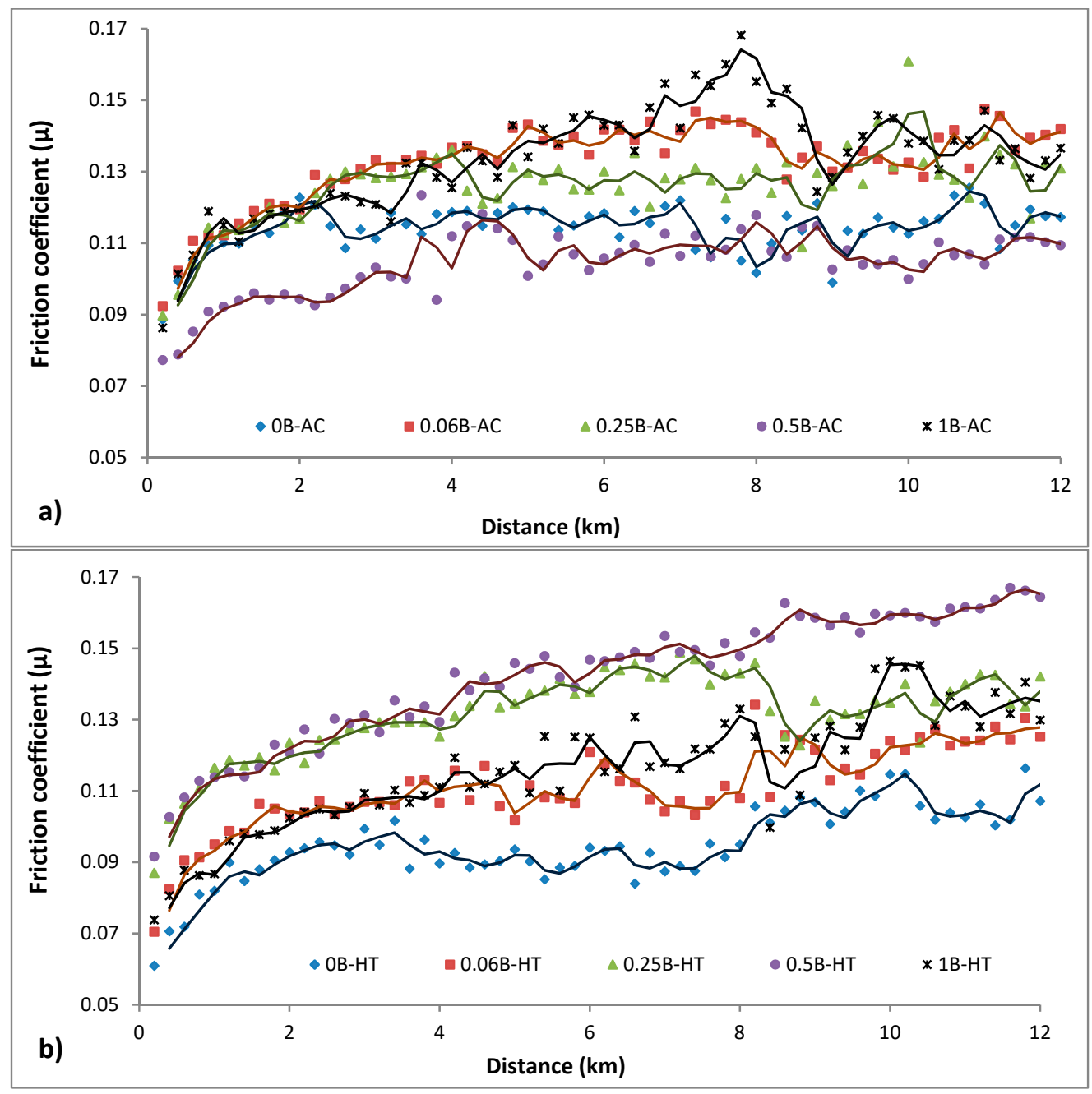

Figure 4. Friction coefficient during the ball-on-disc tests; (a) as-cast alloys and, (b) heat-treated alloys.
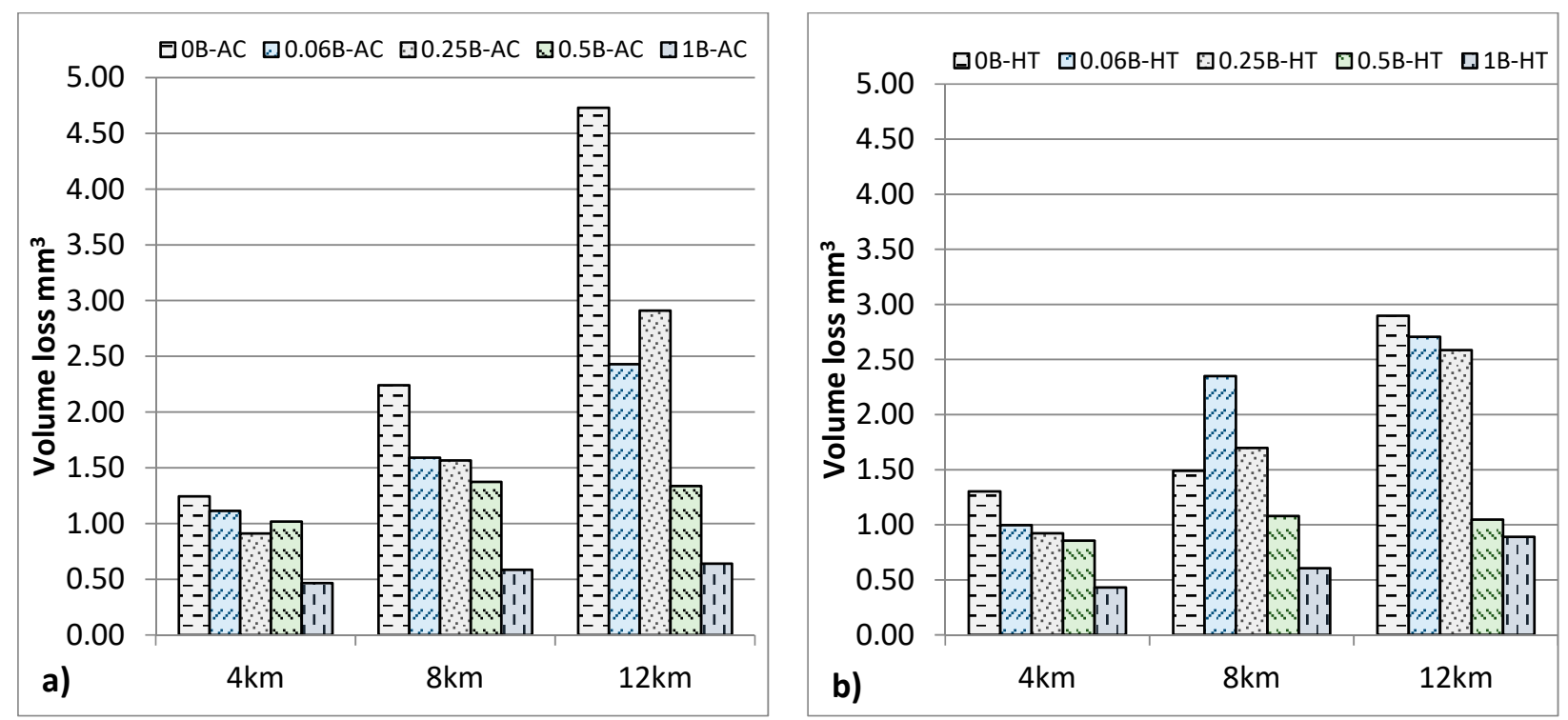

Figure 5. Wear volume of alloys with different boron content according to sliding distance; (a) as-cast alloys and, (b) heattreated alloys. 
In the present study, the influence of friction coefficient or roughness on the wear resistance was not observed. The alloys containing $1 \% \mathrm{~B}$ exhibited high values in these features but also presented high wear resistance; whereas, the $\mathrm{OB}-\mathrm{AC}$ alloy presented low roughness and friction coefficient with high wear. It was previously reported that there is good wear resistance for samples with high roughness [16]. Previous investigations reported enhanced wear behavior for grain refinement and globular carbides evenly distributed $[16,19,34,35]$. In the present study, the boron in the alloys homogenized microstructures, promoting an even distribution of hard precipitates, which led to improved wear resistance. Even a small addition of this element had influence, as observed in the studies regarding these alloys to corrosion and fatigue resistance [31,32].

\subsection{Surface Analysis}

The surface analysis after the tribological test found abrasion to be the main wear mechanism. It was caused by fractured and detached precipitates, which are harder than the matrix. Figure 6 presents the wear tracks of some samples where the holes of those pulled out secondary phases from base material can be observed. Figure 7 shows a higher magnification of broken precipitates. In Figure 8, grooves of abrasive wear in different samples are observed. Abrasion caused by carbide detachment has been widely reported $[19,20,35,36]$. Some studies have even suggested that alloys with lower carbon and carbide content present better wear resistance, since abrasion is reduced and alloys are more prone to strain-induced martensitic transformation [36,37]. In the present study, the carbides dropped off and abrasion grooves were more noticeable in samples without boron and up to $0.25 \%$ of this element. In alloys with 0.5 and $1 \% \mathrm{~B}$, the precipitates were larger and harder, and this phenomenon was less frequent, which suggests a strong bond with the cobalt-rich matrix. In addition, research reported that carbides drop from the matrix during tribocorrosion due to the dissolution of the boundary area of carbides under the galvanic action [20]; while in the study of corrosion resistance of these alloys, improved resistance due to boron additions was observed [31]. Those findings, along with the high hardness of precipitates, could explain the high wear resistance observed in this study in alloys with a high amount of precipitates. The abrasion could also be the cause of the rises and falls in the friction coefficient due to the fracture and detachment of the hard precipitates.

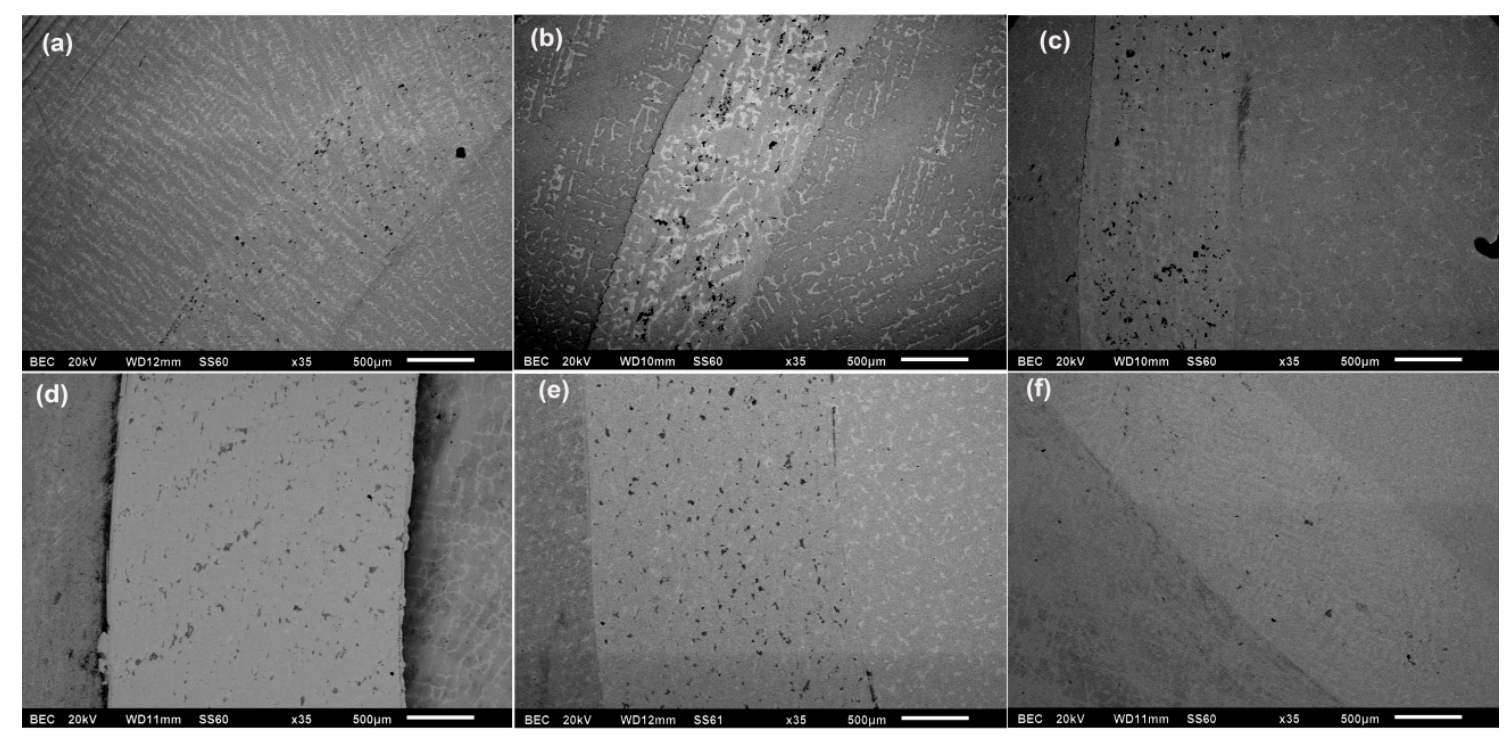

Figure 6. Wear tracks in different samples; (a) $0.25 \mathrm{~B}-\mathrm{AC} 4 \mathrm{~km}$, (b) $0.25 \mathrm{~B}-\mathrm{HT} 4 \mathrm{~km}$, (c) $0.5 \mathrm{~B}-\mathrm{AC} 4 \mathrm{~km}$, (d) $0 \mathrm{~B}-\mathrm{AC} 12 \mathrm{~km}$, (e) $0.06 \mathrm{~B}-\mathrm{HT} 12 \mathrm{~km}$, (f) $1 \mathrm{~B}-\mathrm{HT} 12 \mathrm{~km}$. 

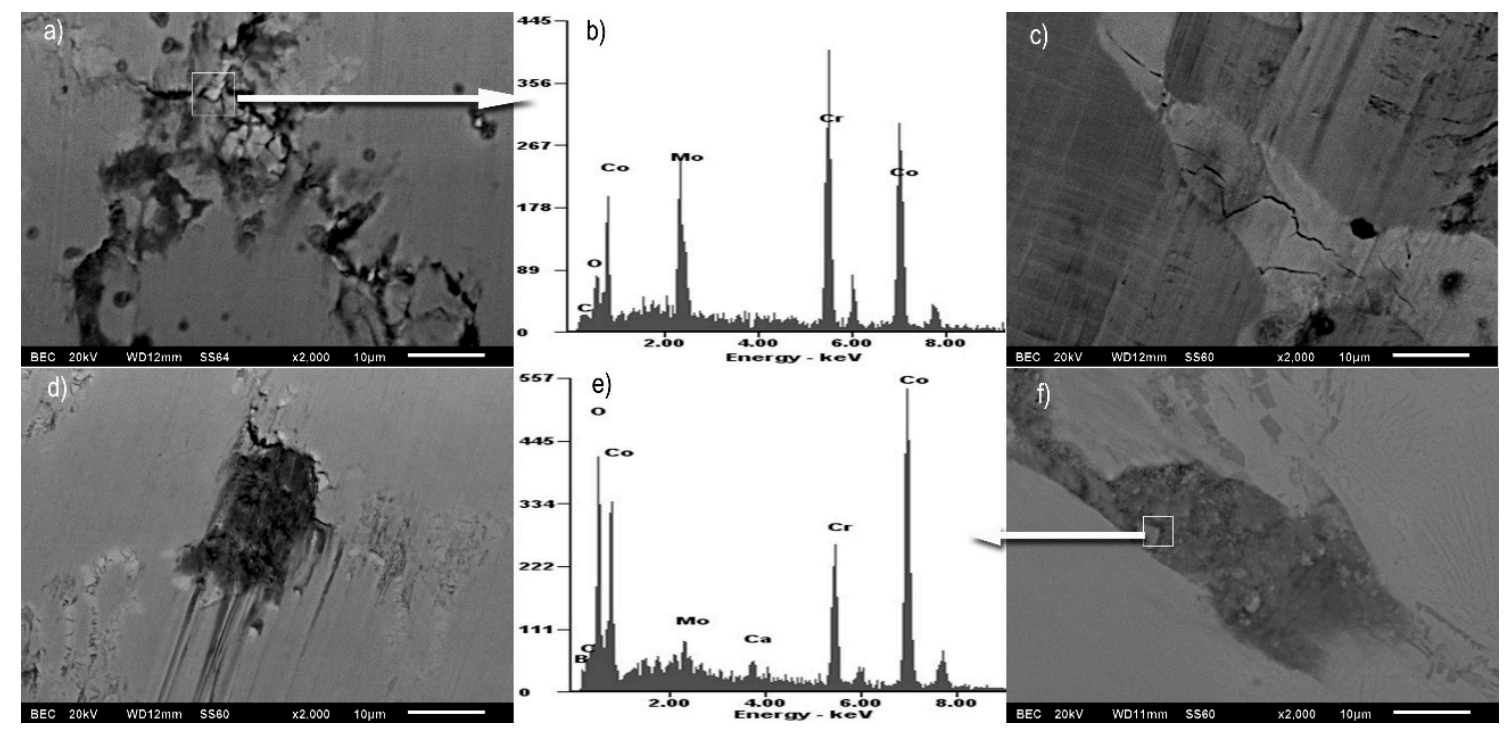

Figure 7. Fracture and detachment of secondary phases. (a) $0 \mathrm{~B}-\mathrm{AC} 12 \mathrm{~km},(\mathbf{b})$ EDS in 0B-AC, (c) 0.06B-AC $4 \mathrm{~km},(\mathrm{~d}) 1 \mathrm{~B}-\mathrm{AC}$ $8 \mathrm{~km},(\mathbf{e})$ EDS in 1B-AC, (f) $1 \mathrm{~B}-\mathrm{HT} 12 \mathrm{~km}$.

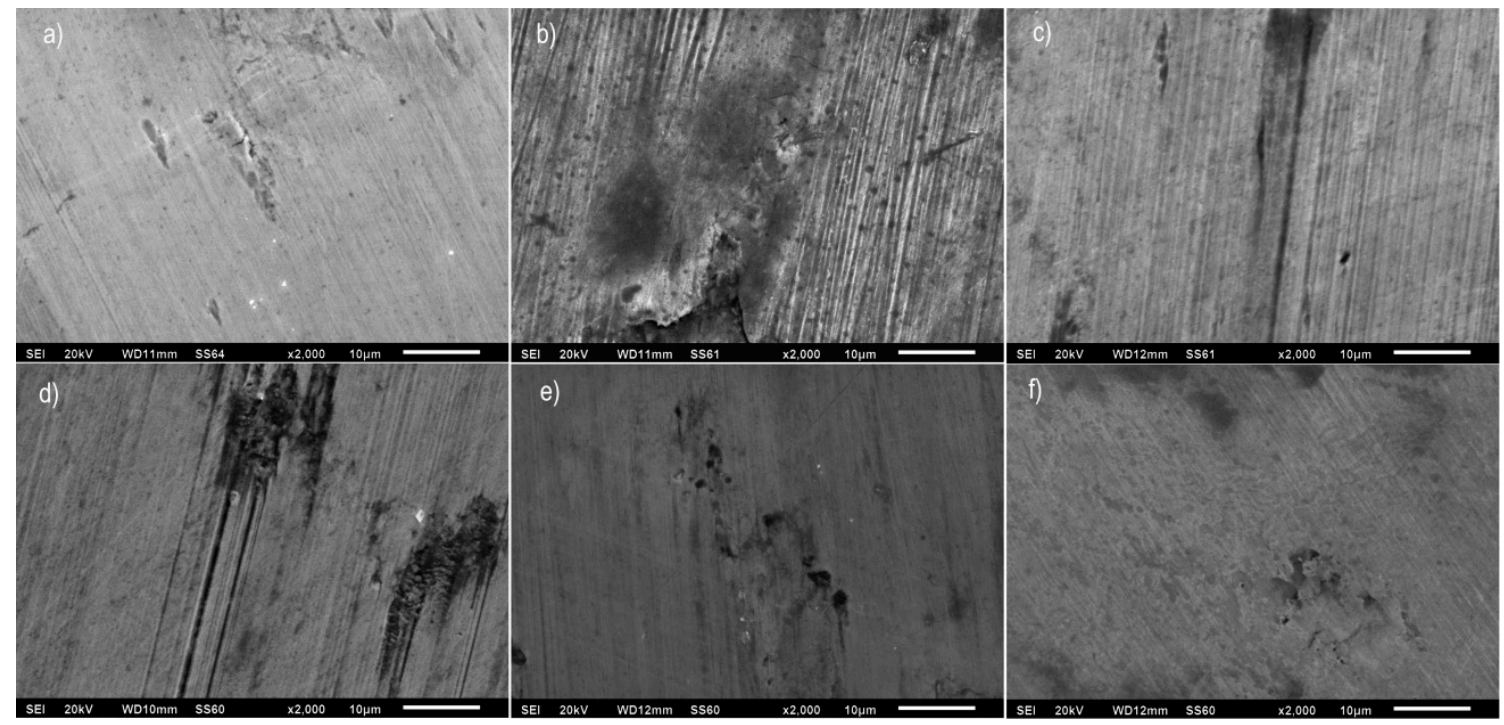

Figure 8. Abrasive wear in: (a) 0B-HT $12 \mathrm{~km}$, (b) 0.06B-AC $12 \mathrm{~km}$, (c) $0.25 \mathrm{~B}-\mathrm{AC} 12 \mathrm{~km}$, (d) $0.5 \mathrm{~B}-\mathrm{AC} 4 \mathrm{~km}$, (e) $1 \mathrm{~B}-\mathrm{AC} 8 \mathrm{~km}$, (f) $1 \mathrm{~B}-\mathrm{HT} 8 \mathrm{~km}$.

The delamination of the material was also observed, which was a product of surface fatigue in samples with sliding distances of 8 and $12 \mathrm{~km}$, as shown in Figure 9. This fatigue delamination diminished in samples with 0.5 and $1 \% \mathrm{~B}$. In the as-cast condition, in the $0.5 \mathrm{~B}-$ AC alloy delamination was only observed after $12 \mathrm{~km}$ and in $1 \mathrm{~B}-\mathrm{AC}$, it was not detected. In the heat treatment condition, delamination was clearly observed in the 0.5B-HT alloy and in 1B-HT it was very slight. A previous study on these alloys reported a decrease in fatigue resistance for heat-treated alloys containing boron respecting the same composition in the as-cast condition [32]. It was found in some cases that this delamination stopped due to hard precipitates under the surface (Figure 9f). 


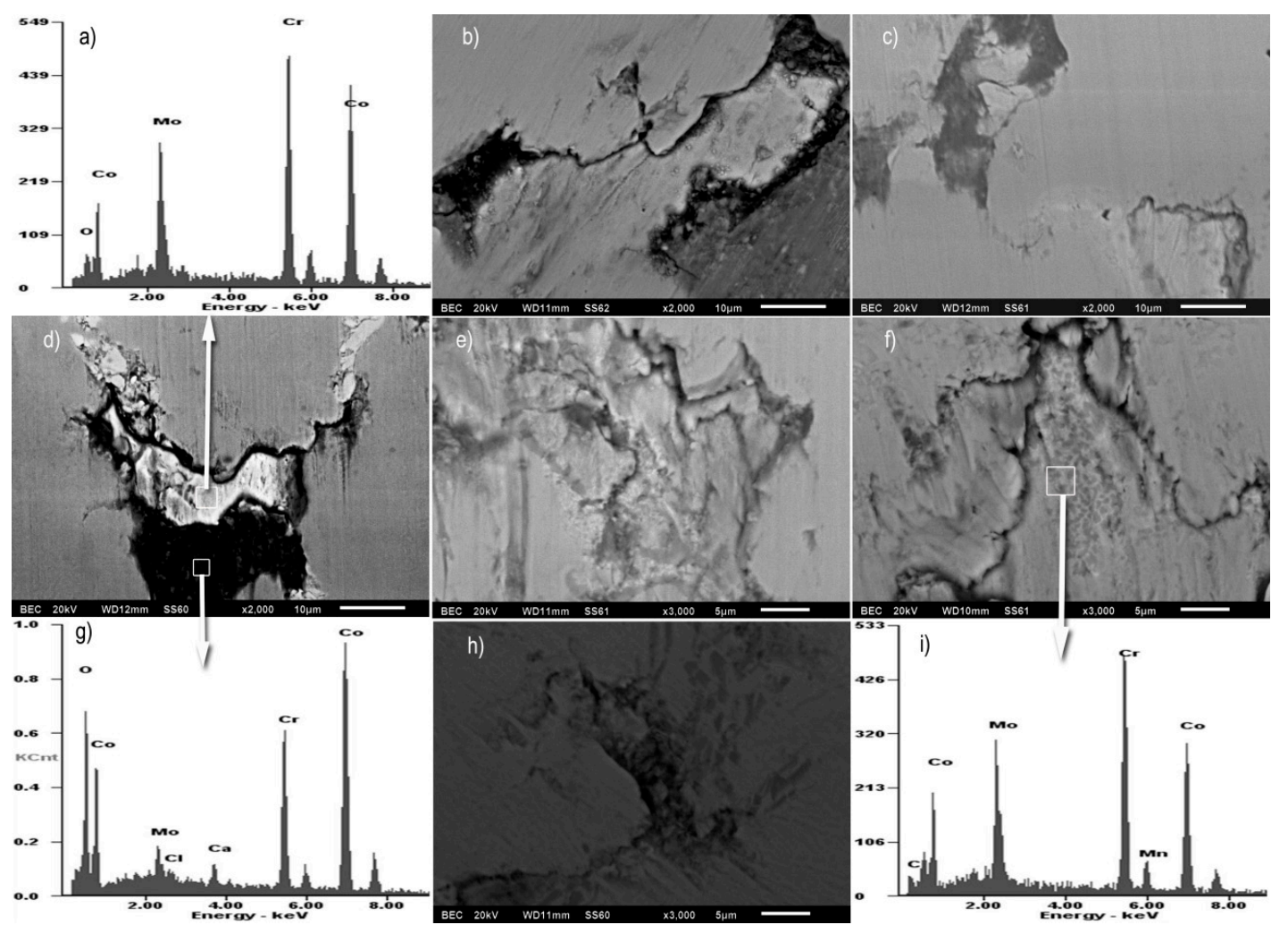

Figure 9. Fatigue delamination; (a) EDS in 0.25B-AC, (b) 0B-HT 8 km, (c) 0.06B-HT 12 km, (d) 0.25B-AC 8 km, (e) 0.5B-AC $12 \mathrm{~km},(\mathbf{f})$ 0.5B-HT $12 \mathrm{~km},(\mathbf{g})$ EDS in 0.25B-AC, (h) 1B-HT $12 \mathrm{~km}$, (i) EDS in 1B-HT.

\section{Conclusions}

The present study evaluated the effect of boron in the tribological behavior of CoCrMo alloys in as-cast and heat treatment conditions. This is the first report that shows the influence of heat treatment on the wear resistance of these alloys with this element and the effect of long sliding distances in wear mechanisms. The study resulted in the following conclusions:

1. Wear resistance was significantly improved by the presence of boron. The more boron content, the less was the wear loss. It was attributed to the precipitation of the harder secondary phases and the even distribution of these phases.

2. The wear resistance was not influenced by the roughness or friction coefficient, but by microstructure, the number of secondary phases and their hardness.

3. The main wear mechanism observed was abrasion caused by the harder secondary phases.

4. Surface delamination due to fatigue was observed after longer sliding distances. It noticeably diminished in 0.5 and $1 \% \mathrm{~B}$ as-cast alloy.

5. Heat treatment at $1200{ }^{\circ} \mathrm{C}$ improved the wear resistance of alloy without boron. The alloys with some content of this element had a similar volumetric wear loss in the as-cast and heat-treated condition. However, heat treatment increased surface delamination.

Author Contributions: Research design M.A.L.H.-R.; testing D.E.L. and G.M.M.-C.; data analysis M.A.L.H.-R., Y.B.-G. and G.M.M.-C.; literature research G.M.M.-C.; manuscript writing Y.B.-G. and D.E.L. All authors have read and agreed to the published version of the manuscript.

Funding: This research received no external funding.

Conflicts of Interest: The authors declare no conflict of interest. 


\section{References}

1. Chen, Q.; Thouas, G.A. Metallic implant biomaterials. Mater. Sci. Eng. R Rep. 2015, 87, 1-57. [CrossRef]

2. Hussein, M.; Mohammed, A.; Al-Aqeeli, N.; Hussein, M.A.; Mohammed, A.S.; Al-Aqeeli, N. Wear Characteristics of Metallic Biomaterials: A Review. Materials 2015, 8, 2749-2768. [CrossRef]

3. Prasad, K.; Bazaka, O.; Chua, M.; Rochford, M.; Fedrick, L.; Spoor, J.; Symes, R.; Tieppo, M.; Collins, C.; Cao, A.; et al. Metallic Biomaterials: Current Challenges and Opportunities. Materials 2017, 10, 884. [CrossRef] [PubMed]

4. Hanawa, T. Metal ion release from metal implants. Mater. Sci. Eng. C 2004, 24, 745-752. [CrossRef]

5. Yan, Y.; Neville, A.; Dowson, D.; Williams, S. Tribocorrosion in implants-assessing high carbon and low carbon Co-Cr-Mo alloys by in situ electrochemical measurements. Tribol. Int. 2006, 39, 1509-1517. [CrossRef]

6. Toh, W.Q.; Tan, X.; Bhowmik, A.; Liu, E.; Tor, S.B. Tribochemical Characterization and Tribocorrosive Behavior of CoCrMo Alloys: A Review. Materials 2018, 11, 30. [CrossRef]

7. Manam, N.S.; Harun, W.S.W.; Shri, D.N.A.; Ghani, S.A.C.; Kurniawan, T.; Ismail, M.H.; Ibrahim, M.H.I. Study of corrosion in biocompatible metals for implants: A review. J. Alloys Compd. 2017, 701, 698-715. [CrossRef]

8. Long, P.H. Medical devices in orthopedic applications. Toxicol. Pathol. 2008, 36, 85-91. [CrossRef]

9. Lord, J.K.; Langton, D.J.; Nargol, A.V.F.; Joyce, T.J. Volumetric wear assessment of failed metal-on-metal hip resurfacing prostheses. Wear 2011, 272, 79-87. [CrossRef]

10. Clemow, A.J.T.; Daniell, B.L. Solution treatment behavior of Co-Cr-Mo alloy. J. Biomed. Mater. Res. 1979, 13, 265-279. [CrossRef]

11. Antunes Altobelli, R.; de Oliveira Lopes, M.C. Corrosion fatigue of biomedical metallic alloys: Mechanisms and mitigation. Acta Biomater. 2012, 8, 937-962. [CrossRef]

12. Herrera, M.; Espinoza, A.; Méndez, J.; Castro, M.; López, J.; Rendón, J. Effect of C content on the mechanical properties of solution treated as-cast ASTM F-75 alloys. J. Mater. Sci. Mater. Med. 2005, 16, 607-611. [CrossRef]

13. Taylor, R.N.J.; Waterhouse, R.B. A study of the ageing behaviour of a cobalt based implant alloy. J. Mater. Sci. 1983, 18, 3265-3280. [CrossRef]

14. Caudillo, M.; Herrera-Trejo, M.; Castro, M.R.; Ramírez, E.; González, C.R.; Juárez, J.I. On carbide dissolution in an as-cast ASTM F-75 alloy. J. Biomed. Mater. Res. 2002, 59, 378-385. [CrossRef] [PubMed]

15. Ramírez, L.E.; Castro, M.; Méndez, M.; Lacaze, J.; Herrera, M.; Lesoult, G. Precipitation path of secondary phases during solidification of the Co-25.5\%Cr-5.5\%Mo-0.26\%C alloy. Scr. Mater. 2002, 47, 811-816. [CrossRef]

16. Tipper, J.L.; Firkins, P.J.; Ingham, E.; Fisher, J.; Stone, M.H.; Farrar, R. Quantitative analysis of the wear and wear debris from low and high carbon content cobalt chrome alloys used in metal on metal total hip replacements. J. Mater. Sci. Mater. Med. 1999, 10, 353-362. [CrossRef] [PubMed]

17. Scholes, S.C.; Unsworth, A. Citation for published item: Permission of Kluwer Law International. Additional information: Use policy Pin-on-plate studies on the effect of rotation on the wear of metal-on-metal samples. J. Mater. Sci. Mater. Med. 2001, 12, 299-303. [CrossRef]

18. St. John, K.R.; Zardiackas, L.D.; Poggie, R.A. Wear evaluation of cobalt-chromium alloy for use in a metal-on-metal hip prosthesis. J. Biomed. Mater. Res. 2004, 68B, 1-14. [CrossRef]

19. Bedolla-Gil, Y.; Hernandez-Rodriguez, M.A.L. Tribological Behavior of a Heat-Treated Cobalt-Based Alloy. J. Mater. Eng. Perform. 2012, 22, 541-547. [CrossRef]

20. Wang, Z.; Yan, Y.; Xing, L.; Su, Y.; Qiao, L. The role of hard phase carbides in tribocorrosion processes for a Co-based biomedical alloy. Tribol. Int. 2017, 113, 370-376. [CrossRef]

21. Bermingham, M.; Bermingham, M.J.; Mcdonald, S.D.; Stjohn, D.H.; Dargusch, M.S. The effect of boron on the refinement of microstructure in cast cobalt alloys. J. Mater. Res. 2011, 26, 951-956. [CrossRef]

22. Opiekun, Z. Kinetics of secondary carbide precipitation in boron-modified cobalt alloys of MAR-M509 type. J. Mater. Sci. 1991, 26, 3386-3391. [CrossRef]

23. Bocchini, P.J.; Sudbrack, C.K.; Noebe, R.D.; Dunand, D.C.; Seidman, D.N. Microstructural and creep properties of boron- and zirconium-containing cobalt-based superalloys. Mater. Sci. Eng. A 2017, 682, 260-269. [CrossRef]

24. Kolb, M.; Freund, L.P.; Fischer, F.; Povstugar, I.; Makineni, S.K.; Gault, B.; Raabe, D.; Müller, J.; Spiecker, E.; Neumeier, S.; et al. On the grain boundary strengthening effect of boron in $\gamma / \gamma^{\prime}$ Cobalt-base superalloys. Acta Mater. 2018, 145, 247-254. [CrossRef]

25. Zhuang, L.Z.; Langer, E.W. Effects of alloy additions on the microstructures and tensile properties of cast Co-Cr-Mo alloy used for surgical implants. J. Mater. Sci. 1989, 24, 4324-4330. [CrossRef]

26. Zhuang, L.Z.; Langer, E.W. Effects of alloy additions on the fatigue properties of cast Co-Cr-Mo alloy used for surgical implants. J. Mater. Sci. 1990, 25, 683-689. [CrossRef]

27. Rodríguez-Castro, G.A.; Reséndiz-Calderon, C.D.; Jiménez-Tinoco, L.F.; Meneses-Amador, A.; Gallardo-Hernández, E.A.; Campos-Silva, I.E. Micro-abrasive wear resistance of CoB/Co2B coatings formed in CoCrMo alloy. Surf. Coat. Technol. 2015, 284, 258-263. [CrossRef]

28. Mu, D.; Shen, B.; Zhao, X. Effects of boronizing on mechanical and dry-sliding wear properties of CoCrMo alloy. Mater. Des. 2010, 31, 3933-3936. [CrossRef]

29. Rosas-Becerra, G.; Mejía-Caballero, I.; Martínez-Trinidad, J.; Palomar-Pardavé, M.; Romero-Romo, M.; Pérez-Pasten-Borja, R.; Campos-Silva, I. Electrochemical Corrosion Behavior of Borided CoCrMo Alloy Immersed in Hanks' Solution. J. Mater. Eng. Perform. 2017, 26, 704-714. [CrossRef] 
30. Alvarez-Vera, M.; Juarez-Hernandez, A.; Gonzalez-Rivera, C.E.; Mercado-Solis, R.D.; Hernandez-Rodriguez, M.A.L. Biotribological response of $\mathrm{CoCr}$ alloy with added boron under ball-on-disc tests. Wear 2013, 301, 243-249. [CrossRef]

31. Hernandez-Rodriguez, M.; Laverde-Cataño, D.; Lozano, D.; Martinez-Cazares, G.; Bedolla-Gil, Y.; Hernandez-Rodriguez, M.A.L.; Laverde-Cataño, D.A.; Lozano, D.; Martinez-Cazares, G.; Bedolla-Gil, Y. Influence of Boron Addition on the Microstructure and the Corrosion Resistance of CoCrMo Alloy. Metals 2019, 9, 307. [CrossRef]

32. Hernandez-Rodriguez, M.A.L.; Mercado-Solis, R.D.; Presbítero, G.; Lozano, D.E.; Martinez-Cazares, G.M.; Bedolla-Gil, Y.; Hernandez-Rodriguez, M.A.L.; Mercado-Solis, R.D.; Presbítero, G.; Lozano, D.E.; et al. Influence of Boron Additions and Heat Treatments on the Fatigue Resistance of CoCrMo Alloys. Materials 2019, 12, 1076. [CrossRef]

33. Sage, M.; Guillaud, C. Méthode d'analyse quantitative des variétés allotropiques du cobalt par les rayons X. Rev. Métallurgie 1950, 47, 139-145. [CrossRef]

34. Saldívar-García, A.J.; López, H.F. Microstructural effects on the wear resistance of wrought and as-cast Co-Cr-Mo-C implant alloys. J. Biomed. Mater. Res. Part A 2005, 74A, 269-274. [CrossRef] [PubMed]

35. Hassani, F.Z.; Ketabchi, M.; Bruschi, S.; Ghiotti, A. Effects of carbide precipitation on the microstructural and tribological properties of Co-Cr-Mo-C medical implants after thermal treatment. J. Mater. Sci. 2016, 51, 4495-4508. [CrossRef]

36. Chiba, A.; Kumagai, K.; Nomura, N.; Miyakawa, S. Pin-on-disk wear behavior in a like-on-like configuration in a biological environment of high carbon cast and low carbon forged Co-29Cr-6Mo alloys. Acta Mater. 2007, 55, 1309-1318. [CrossRef]

37. Chen, Y.; Li, Y.; Kurosu, S.; Yamanaka, K.; Tang, N.; Koizumi, Y.; Chiba, A. Effects of sigma phase and carbide on the wear behavior of CoCrMo alloys in Hanks' solution. Wear 2014, 310, 51-62. [CrossRef] 